\title{
No Decreased Risk of Gastrointestinal Cancers in Users of Metformin in The Netherlands; A Time- Varying Analysis of Metformin Exposure
}

Citation for published version (APA):

de Jong, R. G., Burden, A. M., de Kort, S., van Herk-Sukel, M. P., Vissers, P. A., Janssen, P. K., Haak, H. R., Masclee, A. A., de Vries, F., \& Janssen-Heijnen, M. L. (2017). No Decreased Risk of Gastrointestinal Cancers in Users of Metformin in The Netherlands; A Time-Varying Analysis of Metformin Exposure. Cancer prevention research, 10(5), 290-297. https://doi.org/10.1158/1940-6207.CAPR-16-0277

Document status and date:

Published: 01/05/2017

DOI:

10.1158/1940-6207.CAPR-16-0277

Document Version:

Publisher's PDF, also known as Version of record

Document license:

Taverne

Please check the document version of this publication:

- A submitted manuscript is the version of the article upon submission and before peer-review. There can be important differences between the submitted version and the official published version of record.

People interested in the research are advised to contact the author for the final version of the publication, or visit the DOI to the publisher's website.

- The final author version and the galley proof are versions of the publication after peer review.

- The final published version features the final layout of the paper including the volume, issue and page numbers.

Link to publication

\footnotetext{
General rights rights.

- You may freely distribute the URL identifying the publication in the public portal. please follow below link for the End User Agreement:

www.umlib.nl/taverne-license

Take down policy

If you believe that this document breaches copyright please contact us at:

repository@maastrichtuniversity.nl

providing details and we will investigate your claim.
}

Copyright and moral rights for the publications made accessible in the public portal are retained by the authors and/or other copyright owners and it is a condition of accessing publications that users recognise and abide by the legal requirements associated with these

- Users may download and print one copy of any publication from the public portal for the purpose of private study or research.

- You may not further distribute the material or use it for any profit-making activity or commercial gain

If the publication is distributed under the terms of Article 25fa of the Dutch Copyright Act, indicated by the "Taverne" license above, 
No Decreased Risk of Gastrointestinal Cancers in Users of Metformin in The Netherlands; A Time-Varying Analysis of Metformin Exposure

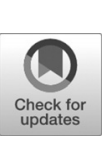

Roy G. de Jong ${ }^{1,2}$, Andrea M. Burden ${ }^{3,4}$, Sander de Kort ${ }^{2}$, Myrthe P. van Herk-Sukel ${ }^{5}$, Pauline A. Vissers ${ }^{6}$, Paddy K. Janssen ${ }^{3,4,7,8}$, Harm R. Haak ${ }^{9,10,11}$, Ad A. Masclee ${ }^{12}$, Frank de Vries ${ }^{3,4,11,13}$, and Maryska L. Janssen-Heijnen ${ }^{14,15}$

\section{Abstract}

Previous studies on metformin use and gastrointestinal (GI) cancer risk have yielded inconclusive results on metformin's chemoprotective effects. We aimed to evaluate GI cancer risk in users of metformin in The Netherlands using a time-varying approach in a large population-based database. A cohort study was performed using the NCR-PHARMO database. Patients using $\geq 1$ non-insulin antidiabetic drug (NIAD) during 1998 to 2011 were included $(N=57,621)$. Exposure to NIADs was modeled time-varyingly. Cox regression analysis estimated HRs of GI cancers in current metformin users versus current users of other NIADs. Covariables included age, sex, drugs known to impact cancer risk, history of hospitalization, and starting year of followup. A sensitivity analysis was performed, applying a new-user design. Current use of metformin was not associated with a decreased risk of GI cancer [HR, 0.97; 95\% confidence interval (CI), $0.82-1.15]$ or specific GI cancer sites. The sensitivity analysis yielded comparable results. No decreasing trends were observed with increasing cumulative dose of metformin [HR 1.05, 95\% CI, 0.85-1.28; HR 0.89, 95\% CI, 0.73-1.10; HR 0.96, 95\% CI, 0.771.19 for dose tertiles low ( $<405 \mathrm{~g}$ ), medium (405-999 g), and high $(\geq 999 \mathrm{~g})]$. In contrast, an increased risk of pancreatic cancer was found in current users of metformin plus insulin (HR, 4.90; 95\% CI, 2.64-9.10). In conclusion, no decreased risk of GI cancer was found in current metformin users compared with current users of other NIADs. Variations in the exposure definition of metformin use may be one of the explanations of previously found reduced cancer risks in metformin users. Cancer Prev Res; 10(5); 290-7. (92017 AACR.

\section{Introduction}

Metformin is an antidiabetic drug (ADD) that is widely used as the preferred first-line treatment for hyperglycemia in type 2 diabetes mellitus (T2DM). The Dutch guideline for the treatment of T2DM advises metformin as first-line treatment as well, beside lifestyle advice such as dietary modification, physical exercise, and weight reduction (1)

Metformin not only effectively lowers the blood glucose concentration through inhibition of gluconeogenesis and glycogenolysis in the liver, but is also known to decrease insulin resistance and hyperinsulinemia through the insulin/IGF-1 signaling pathway $(2,3)$. Because insulin resistance is known to be a risk factor for cancer development, metformin may have a role in chemoprevention of cancer (4-6). Other ways through which metformin may reduce cancer risk are: (1) direct activation of AMP-activated protein kinase (AMPK) signaling, which leads to inhibition of the mTOR signaling pathway, and subsequently to reduced cell proliferation, protein synthesis, and tumor angiogenesis (4); (2) metformin may have antiinflammatory effects on malignant cells and may inhibit malignant stem cells, which are important in cancer initiation, recurrence, and resistance to chemotherapies (7)
'Department of Internal Medicine, VieCuri Medical Centre, Venlo, the Netherlands. ${ }^{2}$ Division of Gastroenterology and Hepatology, Department of Interna Medicine, GROW - School for Oncology and Developmental Biology, Maastricht University Medical Centre+, Maastricht, the Netherlands. ${ }^{3}$ Department of Clinical Pharmacy and Toxicology, Maastricht University Medical Centre+, Maastricht, the Netherlands. ${ }^{4}$ Utrecht Institute for Pharmaceutical Sciences, Division of Pharmacoepidemiology and Clinical Pharmacology, Utrecht University, Utrecht, the Netherlands. ${ }^{5}$ PHARMO Institute for Drug Outcomes Research, Utrecht, the Netherlands. ${ }^{6}$ Department of Research, Netherlands Comprehensive Cancer Organization, Utrecht, the Netherlands. ${ }^{7}$ Utrecht Institute for Pharmaceutical Sciences, Division of Pharmacology, Utrecht University, Utrecht, the Netherlands. ${ }^{8}$ Department of Central Hospital Pharmacy, VieCuri Medical Centre, Venlo, the Netherlands. ${ }^{9}$ Department of Internal Medicine, Máxima Medical Centre Eindhoven, Eindhoven, the Netherlands. ${ }^{10}$ Division of General Internal Medicine, Department of Internal Medicine, Maastricht University Medical Centre+, Maastricht, the Netherlands. "Department of Health Services Research, CAPHRI School for Public Health and Primary Care, Maastricht University Medical Centre+, Maastricht, the Nether- lands. ${ }^{12}$ Division of Gastroenterology and Hepatology, Department of Internal Medicine, NUTRIM - School of Nutrition and Translational Research in Metabolism, Maastricht University Medical Centre+, Maastricht, the Netherlands. ${ }^{13} \mathrm{MRC}$ Life-course Epidemiology Unit, University of Southampton, Southampton, United Kingdom. ${ }^{14}$ Department of Epidemiology, GROW - School for Oncology and Developmental Biology, Maastricht University Medical Centre+, Maastricht, the Netherlands. ${ }^{15}$ Department of Clinical Epidemiology, VieCuri Medical Centre, Venlo, the Netherlands.

Note: Supplementary data for this article are available at Cancer Prevention Research Online (http://cancerprevres.aacrjournals.org/)

Corresponding Author: Roy G. de Jong, Department of Internal Medicine VieCuri Medical Centre, Tegelseweg 210, 5912 BL, Venlo, the Netherlands. Phone: +31 433884 202; Fax: +31 433875 093; E-mail: roy.dejong@maastrichtuniversity.nl

doi: 10.1158/1940-6207.CAPR-16-0277

(c)2017 American Association for Cancer Research 
Observational studies have shown reduced risks of up to $64 \%$ for colorectal cancer, $94 \%$ for liver cancer, and $85 \%$ for pancreatic cancer in patients with T2DM using metformin (8-15). However, the validity of the reported risk reductions in observational studies may be limited due to methodological issues, such as confounding by indication, prevalent user bias, and time-related biases (16-18). Moreover, recent studies that have used a time-varying approach of metformin exposure could not confirm the lower risk of several cancers with use of metformin $(19,20)$. Although metformin may contain antineoplastic properties based on the aforementioned in vitro evidence, this effect may not be clinically relevant and therefore not visible when applying an optimal exposure definition of metformin use in an observational design.

The aim of our study was to evaluate the risk of gastrointestinal (GI) cancers in patients with T2DM using metformin applying a time-varying approach to ADD exposure, and to show differences between a prevalent user design and a new-user design.

\section{Materials and Methods}

\section{Data source}

Data for this population-based cohort study were obtained from the PHARMO Database Network and linked at the individual patient level to the Eindhoven area of the Netherlands Cancer Registry (NCR). The construct and validity of the linked database have been described elsewhere (21). The Eindhoven area of the NCR, maintained by the Netherlands Comprehensive Cancer Organisation (NCCO), covers a demographic region with approximately 2.4 million inhabitants ( $15 \%$ of the Dutch population). Trained registration clerks actively collect data on newly diagnosed cancers, patient characteristics, staging, and initial treatment from hospital medical records. Vital status is obtained by linkage to Dutch municipal records.

The PHARMO Database Network is a large, patient-centric data network including linked observational databases designed for drug safety and outcomes research. For this study, the Out-patient (community) Pharmacy Database was used, which contains longitudinal drug dispensing records, and included information on dispensing date, dose descriptions, and amount dispensed. All drugs are coded according to their Anatomical Therapeutic Chemical/Defined Daily Dose Classification (ATC/DDD) code (22). Both the NCR and the PHARMO Database Network are recognized as high-quality data sources for (pharmaco-)epidemiological research that have collected information in overlapping regions in the Netherlands for a period of over 10 years (21).

\section{Study design and population}

We conducted a cohort study of all adult patients aged $\geq 30$ years with at least one drug dispensing for an ADD [ATC codes "A10A" insulins, or "A10B" non-insulin antidiabetic drugs (NIAD)] in the NCR-PHARMO region between January 1 , 1998, and December 31, 2011 (Fig. 1). The date of first recorded ADD defined the index date. We restricted the cohort to patients aged $\geq 30$ years at the time of their first recorded prescription, as GI cancer rarely occurs before that age and to reduce misclassification by including type 1 diabetic patients. Patients for whom the first recorded ADD was insulin (ATC code "A10A") were excluded as they were more likely to have type 1 diabetes mellitus. Since coverage of the PHARMO database has gradually increased over time, there is a small chance that some prevalent T2DM patients were excluded, as patients could have entered the database at a later stage of their disease. Patients diagnosed with any type of GI cancer before the index date were excluded.

\section{Exposure classification}

Follow-up time for all subjects was divided into fixed 90-day time intervals in order to model drug exposure over time in a timevarying way. Exposure to metformin and nonmetformin NIADs (other NIADs) was defined at the beginning of every 90-day interval. If a patient received a metformin or other NIAD prescription in the 90-days prior to the start of an interval, they were classified as a "current user" of that drug, otherwise they were classified as a "past user." All patients were classified as "current user" of either metformin or a nonmetformin other NIAD at each time interval, but they could move between current and past use throughout follow-up.

The cumulative dose of metformin was calculated at each current metformin use interval by summation of the total dose of each metformin prescription during the previous current use intervals. The whole sample median value was used to impute missing values of the recorded dose per tablet and for missing and/or extreme values of the amount of tablets dispensed. Cumulative dose at the end of follow-up was stratified by tertiles of cumulative metformin dose and classified as low (<405 g), medium (405-998 g), and high ( $\geq 999 \mathrm{~g})$ cumulative dose.

\section{Outcomes}

All patients were followed from the index date until a first ever diagnosis of a GI cancer, death from any cause, end of registration within the PHARMO catchment area, or end of data collection (December 31, 2011), whichever came first. GI cancers were classified according to the International Classification of Diseases of oncology (23). These included "any GI cancer" (C15-26), esophageal cancer (C15), gastric cancer (C16), small intestinal cancer (C17), colorectal cancer (CRC, C18-C20), hepatic cancer (C22), biliary tract cancer (C23: gallbladder, and C24: extrahepatic bile duct cancer), and pancreatic cancer (C25).

\section{Covariables}

A number of covariables were considered as confounders based on the current literature. As time-fixed covariables sex and history of hospitalization prior to the index date (hospitalization categories 0 or $\geq 1$ ) were considered. Time-dependent covariables were determined at the start of every 90-day time period and included age, the duration of diabetes in years (time since first recorded NIAD dispensing), and the use of other drugs known to impact GI cancer risk in the 90 days prior to the start of each interval [statins, aspirin, non-aspirin non-steroidal anti-inflammatory drugs (NSAID), proton pump inhibitors, bisphosphonates, tamoxifen, oral contraceptives, and insulin). In addition, the use of helicobacter pylori (H. pylori) eradication therapy was used as proxy-indicator for $\mathrm{H}$. pylori infection. Also, the year of start of follow-up was included as covariable as the index date of current metformin users and current users of other NIADs differed significantly at baseline (Table 1).

\section{Statistical analysis}

Differences in demographic characteristics between current users of metformin and current users of other NIADs at baseline were compared using the Mann-Whitney $U$ test for continuous variables and the $\chi^{2}$ test for categorical variables. 
de Jong et al. All patients (age $\geq 30$ years) with $\geq 1$ recorded anti-
diabetic drug (ADD) dispensing (ATC 'A10A or
A10B') between 1 January, 1998, and 31 December,
2011, within the Out-patient Pharmacy Database of
the PHARMO Database Network $(n=67,459)$

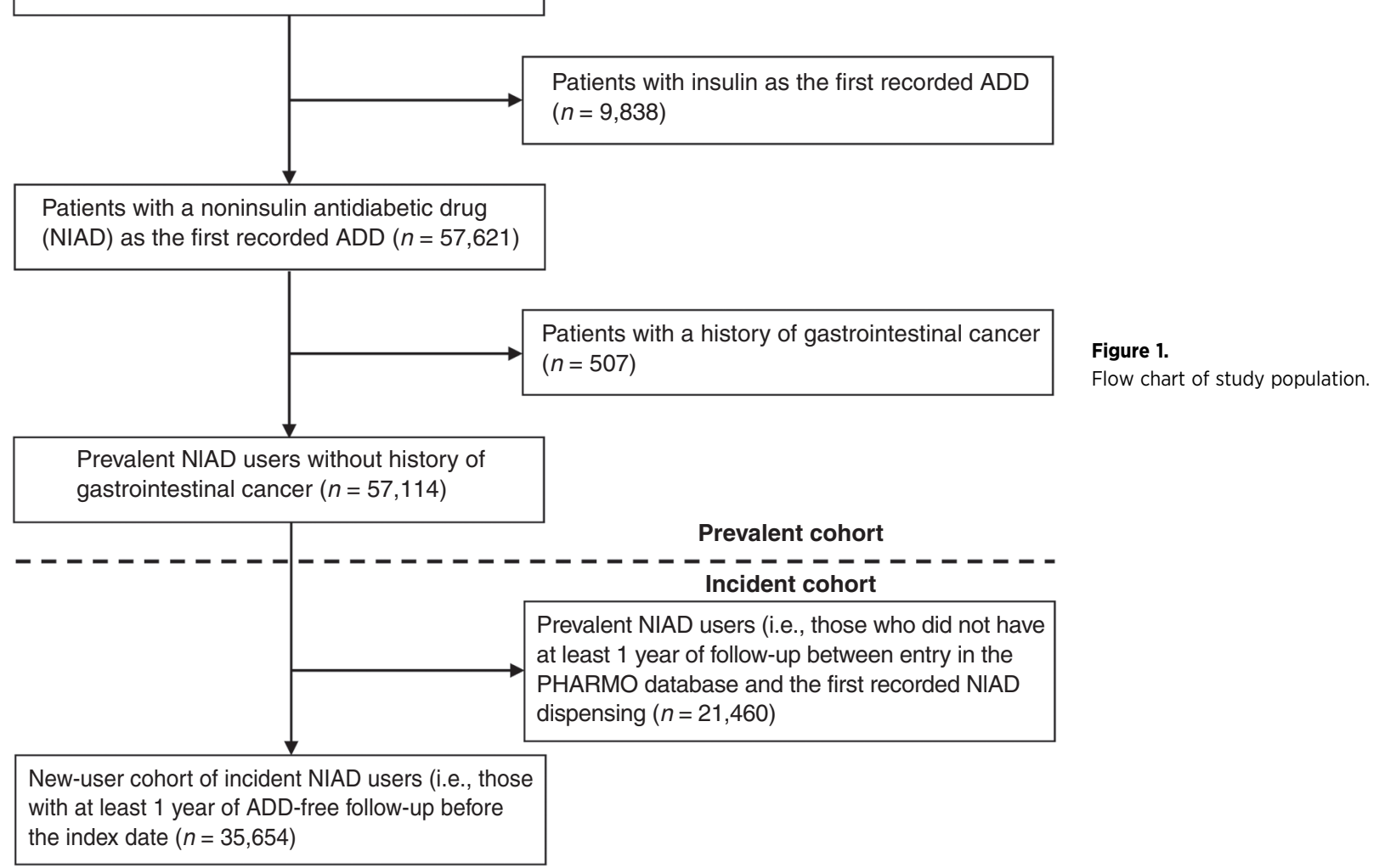

Incidence rates per 100,000 person-years of follow-up were calculated by dividing the number of events by the total amount of person-years of follow-up. Overall and site-specific HRs and
95\% confidence intervals (CI) of GI cancer in current users of metformin versus current users of other NIADs were calculated using time-varying Cox proportional hazards models. Stratified

Table 1. Baseline characteristics of current users of metformin or other NIADs

\begin{tabular}{|c|c|c|c|c|c|}
\hline \multirow[b]{2}{*}{ Characteristic } & \multicolumn{2}{|c|}{ Current metformin users } & \multicolumn{2}{|c|}{ Current other NIADs users } & \multirow[b]{2}{*}{$P$ value $^{\text {a }}$} \\
\hline & $n=37,215$ & & $\overline{n=19, \varepsilon}$ & & \\
\hline Age (mean, SD) & 63.5 & 12.7 & 67.0 & 12.9 & $<0.01$ \\
\hline Sex $(n, \%$ male $)$ & 18,151 & 48.8 & 9,353 & 47.0 & $<0.01$ \\
\hline Year of index date (mean, SD) & 2006 & 3.4 & 2002 & 3.4 & $<0.01$ \\
\hline \multicolumn{6}{|l|}{ ADD use $(n, \%)^{\mathbf{b}}$} \\
\hline Metformin & 37,215 & 100.0 & 0 & 0.0 & $<0.01$ \\
\hline SU & 4,621 & 12.4 & 19,166 & 96.3 & $<0.01$ \\
\hline Thiazolidinediones & 357 & 1.0 & 632 & 3.2 & $<0.01$ \\
\hline Meglitinides & 9 & 0.0 & 54 & 0.3 & $<0.01$ \\
\hline Incretins & 71 & 0.2 & 53 & 0.3 & 0.06 \\
\hline \multicolumn{6}{|l|}{ Use of other drugs $(n, \%)^{c}$} \\
\hline Antihypertensives & 21,653 & 58.2 & 10,246 & 51.5 & $<0.01$ \\
\hline Aspirin & 6,326 & 17.0 & 3,102 & 15.6 & $<0.01$ \\
\hline Bisphosphonates & 922 & 2.5 & 549 & 2.8 & 0.04 \\
\hline H. pylori eradication therapy & 41 & 0.1 & 9 & 0.1 & 0.01 \\
\hline Non-aspirin NSAIDs & 4,832 & 13.0 & 2,630 & 13.2 & 0.43 \\
\hline Proton pump inhibitors & 6,478 & 17.4 & 2,702 & 13.6 & $<0.01$ \\
\hline Statins & 14,898 & 40.0 & 4,408 & 22.2 & $<0.01$ \\
\hline \multicolumn{6}{|l|}{ History of hospitalization $(n, \%)$} \\
\hline 0 hospitalizations & 22,621 & 60.8 & 14,310 & 71.9 & \\
\hline$\geq 1$ hospitalizations & 14,594 & 39.2 & 5,589 & 28.1 & $<0.01$ \\
\hline
\end{tabular}

${ }^{a} P$ value based on Mann-Whitney $U$ test for continuous variables and $\chi^{2}$ test for categorical variables.

${ }^{\mathrm{b}}$ At the start of follow-up (t0),

'During 90 days before the index date. 
Table 2. HRs of gastrointestinal cancer overall in current metformin users compared with current other NIAD users

\begin{tabular}{|c|c|c|c|c|c|c|c|c|}
\hline \multirow[b]{2}{*}{ Exposure category } & \multicolumn{4}{|c|}{ Prevalent-user design } & \multicolumn{4}{|c|}{ New-user design } \\
\hline & $\begin{array}{l}\text { Events } \\
(N=1,076)\end{array}$ & IR & $H^{a}(95 \% \mathrm{Cl})$ & $\mathrm{HR}^{\mathrm{b}}(95 \% \mathrm{Cl})$ & $\begin{array}{l}\text { Events } \\
(N=612)\end{array}$ & IR & $\mathrm{HR}^{\mathrm{a}}(95 \% \mathrm{CI})$ & $\mathrm{HR}^{\mathrm{b}}(95 \% \mathrm{CI})$ \\
\hline Current other NIADs ${ }^{c}$ & 214 & 457 & Ref. & Ref. & 120 & 556 & Ref. & Ref. \\
\hline Current metformin & 624 & 376 & $0.96(0.81-1.13)$ & $0.97(0.82-1.15)$ & 361 & 391 & $0.91(0.73-1.14)$ & $0.79(0.59-1.06)$ \\
\hline \multicolumn{9}{|l|}{ Stratified by treatment stage ${ }^{d}$} \\
\hline Metformin only & 277 & 341 & $0,83(0.69-1.01)$ & $0.89(0.73-1.07)$ & 208 & 359 & $0.81(0.63-1.03)$ & $0.75(0.55-1.04)$ \\
\hline Metformin + SU & 269 & 432 & $1,07(0.89-1.29)$ & $1.07(0.89-1.29)$ & 117 & 450 & $1.06(0.81-1.39)$ & $0.85(0.60-1.21)$ \\
\hline Metformin + other NIADs & 15 & 247 & $0,74(0.43-1.26)$ & $0.75(0.46-1.28)$ & 11 & 320 & $0.97(0.52-1.82)$ & $0.79(0.34-1.84)$ \\
\hline Metformin + insulin & 63 & 379 & $1,15(0.86-1.54)$ & $1.06(0.78-1.43)$ & 25 & 496 & $1.57^{+}(1.00-2.47)$ & $0.74(0.36-1.51)$ \\
\hline \multicolumn{9}{|l|}{ Stratified by cumulative dose $e^{e}$} \\
\hline Low & 201 & 376 & $0.93(0.76-1.14)$ & $1.05(0.85-1.28)$ & 143 & 429 & $0.95(0.74-1.23)$ & $0.78(0.54-1.11)$ \\
\hline Medium & 196 & 343 & $0.88(0.72-1.08)$ & $0.89(0.73-1.10)$ & 109 & 324 & $0.76(0.58-1.01)$ & $0.73(0.51-1.04)$ \\
\hline High & 227 & 408 & $1.10(0.90-1.36)$ & $0.96(0.77-1.19)$ & 109 & 430 & $1.10(0.82-1.47)$ & $0.91(0.62-1.34)$ \\
\hline Past metformin & 194 & 361 & $0.95(0.77-1.16)$ & $0.87(0.70-1.07)$ & 115 & 397 & $0.95(0.72-1.25)$ & $0.74(0.52-1.06)$ \\
\hline Past other NIADs & 44 & 281 & $0.66^{*}(0.48-0.92)$ & $0.61^{*}(0.44-0.84)$ & 16 & 199 & $0.41^{*}(0.24-0.69)$ & $0.40^{*}(0.21-0.76)$ \\
\hline
\end{tabular}

Abbreviation: IR, incidence rate per 100,000 person-years.

${ }^{\mathrm{a}}$ Age and sex adjusted.

${ }^{\mathrm{b}}$ Adjusted for age, sex, use of statins, insulin, history of hospitalization, duration of diabetes, and year of start of follow-up.

${ }^{\mathrm{C} E x c l u d i n g}$ metformin.

${ }^{d}$ Fully adjusted model not adjusted for insulin use.

eLow: <405 g; Medium: 405-998 g; High: $\geq 999$ g.

"Statistically significant with $P<0.05$.

analyses were performed by sex, and by stratifying current metformin use by treatment stage and tertiles of cumulative dose. Subgroups of current metformin use by treatment stage included metformin monotherapy, metformin plus a sulfonylurea (SU) derivative, metformin plus another (non-SU) NIAD, and metformin plus insulin (regardless of other NIAD use). Potential confounders were entered into the regression models if they independently changed the $\beta$-coefficient for current metformin use by at least $5 \%$ in a univariate analysis.

\section{Sensitivity analyses}

Sensitivity analyses with a new-user design were performed to account for prevalent user bias. The main analyses were repeated with an inception cohort of incident NIAD users only (Fig. 1). To create an inception cohort of incident NIAD users, we excluded all prevalent NIAD users, i.e., those who did not have at least 1 year of follow-up between entry in the PHARMO database and the first recorded NIAD dispensing. Data management and statistical analyses were conducted using SAS 9.4 software.

\section{Results}

\section{Baseline characteristics}

At the start of follow-up, 37,215 T2DM patients were current metformin users and 19,899 were current users of other NIADs (Table 1). Current metformin users were on average younger (mean age, 63.5 vs. 67.0 years, $P<0.01$ ) and more often males ( $48.8 \%$ vs. $47.0 \%, P<0.01$ ) compared with current other NIAD users. The year of start of follow-up was more recent for current metformin users than current other NIAD users (mean, 2006 vs. $2002, P<0.01)$. Most diabetic patients started follow-up either on metformin monotherapy or on SU $(96.3 \%$ of current other NIAD users). Furthermore, current metformin users used more other drugs besides ADDs as compared with other NIAD users, such as statins $(40.0 \%$ vs. $22.2 \%, P<0.01)$, aspirin $(17.0 \%$ vs. $15.6 \%, P<0.01)$, anti-hypertensives ( $58.2 \%$ vs. $51.5 \%, P<0.01)$, and proton pump inhibitors $(17.4 \%$ vs. $13.6 \%, P<0.01)$. Current metformin users were being hospitalized prior to the index date more often $(39.2 \%$ vs. $28.1 \%, P<0.01)$.

\section{GI cancer overall}

During more than 280,000 person-years of follow-up (mean, 4.9 years per person), 1,076 GI cancers were observed (IR, 381 per 100,000 person-years). No statistically significant decreased risk of GI cancer was observed in current metformin users compared with current other NIAD users (fully adjusted HR 0.97; 95\% CI, $0.82-1.15$; Table 2). Stratified analyses of subgroups of current metformin use by treatment stage and tertiles of cumulative dose did not reveal a decreased risk of GI cancer. Furthermore, the sensitivity analysis and stratified analysis by sex yielded similar results (Table 2 and Supplementary Table S1, respectively).

\section{GI cancer sites}

In the site-specific analyses, no significant differences in HRs of GI cancers were observed in current metformin users versus current other NIAD users (Table 3). However, a statistically significant increased HR of pancreatic cancer was observed in the subgroup of current users of metformin plus insulin (fully adjusted HR 4.90; 95\% CI, 2.64-9.10) and in female current metformin users (fully adjusted HR 1.95; 95\% CI, 1.01-3.76; Supplementary Table S2). Furthermore, there were no trends with increasing cumulative dose of metformin. In addition, the new-user design did not show statistically significant decreased HRs of GI cancer sites in current metformin users compared with current other NIAD users (Table 4), whereas increased HRs of pancreatic cancer with current use of metformin plus a SU derivative and metformin plus insulin remained (fully adjusted HR 1.98; 95\% CI, 1.10-3.59 and fully adjusted HR 10.26; 95\% CI, 4.96-21.22, respectively).

\section{Discussion}

In this population-based cohort study, in which we used a timevarying approach to determine metformin exposure in diabetic patients, no reduced risk of GI cancer was found when comparing current use of metformin with current use of other NIADs. In 
de Jong et al.

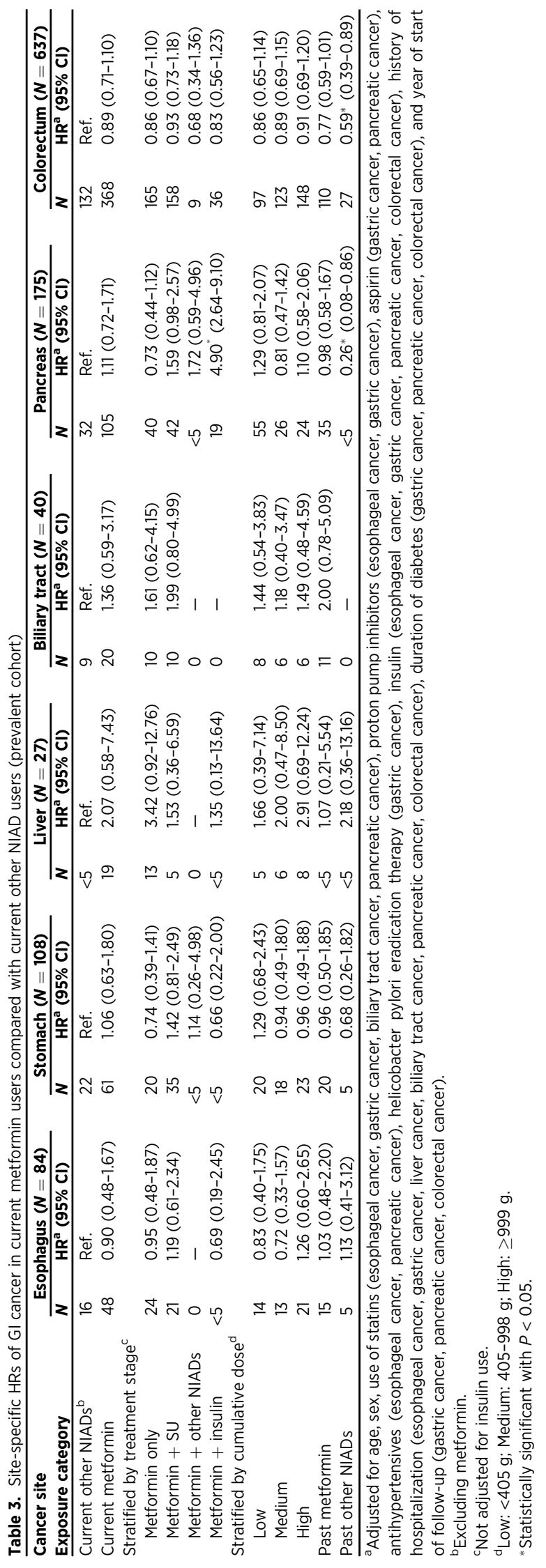

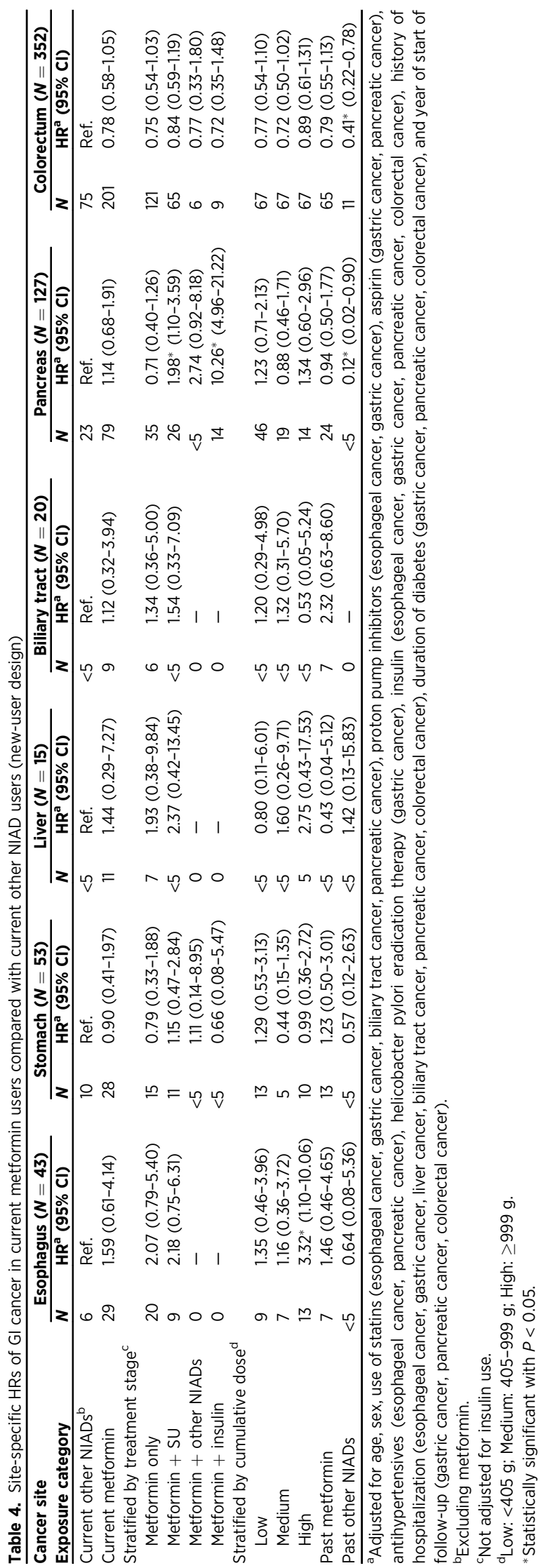


addition, results from the sensitivity analysis, in which a new-user design was applied, did not significantly differ from the main analyses with a prevalent cohort of NIAD users. The risk of pancreatic cancer was increased in female current users of metformin, and in current users of metformin combined with insulin compared with current other NIAD users in both the main and sensitivity analysis.

The results of this study add to the evidence of recently published observational studies on the effect of metformin and (GI) cancer risk $(20,24-31)$. These studies showed no statistically significant reductions in GI cancer risk in users of metformin compared with users of other NIADs. Furthermore, these studies meet methodological standards due to a time-varying definition of exposure to metformin and because potential (time-related) biases have been adequately accounted for. The applied timevarying approach of metformin exposure in this study minimizes exposure misclassification and time-related bias. In addition, the results of our study will support future meta-analyses on the risk of GI cancer with use of metformin, and will help draw a firmer conclusion on metformin's chemoprotective effects.

The observed increased risk of pancreatic cancer in current users of metformin plus insulin and plus a SU derivative might be explained by the potential mitogenic effects of insulin and $\mathrm{SU}$, as insulin secretagogues. A recent meta-analysis of observational studies reported an increased risk of pancreatic cancer with use of insulin versus NIADs (32). However, the authors advised cautious interpretation of their results as they had identified various methodological issues such as confounding by indication and time-related bias in multiple included studies (32). Bodmer and colleagues have reported an almost doubled risk of pancreatic cancer in users of SU (Adjusted OR 1.90; 95\% CI, 1.32-2.74; ref. 10). However, also with respect to $\mathrm{SU}$, studies on cancer risk have reported contrasting results (33). In addition, the increased risk of pancreatic cancer in these subgroups of current metformin use may be explained by protopathic bias. It is possible that SU or insulins were added to metformin treatment as a result of disturbances in glucose homeostasis by an emerging pancreatic cancer.

Meta-analyses of observational studies on metformin and cancer risk have presented mixed results for various GI cancers, possibly due to the high heterogeneity among included studies (e. g., in definition of T2DM, type of database, geographic region; refs. 33-40). Meta-analyses on metformin and cancer risk often combine results of observational studies with different types of exposure definitions to metformin, which potentially cause varying amounts of exposure misclassification and time-related bias. Future meta-analyses on the risk of cancer with use of metformin would benefit from an in-depth description of possible biases and confounding in all included studies, and by performing stratified analyses including only studies with a low level of confounding and bias. In fact, Gandini and colleagues performed a systematic review and meta-analysis of observational studies on metformin and cancer risk with emphasis on studies controlling for confounding by body mass index (BMI) and for time-related biases (41). Of the 47 included studies, only 18 were deemed to not have time-related biases. Regarding GI cancer risk, only the risk of colorectal cancer remained slightly decreased when analyzing studies without time-related bias $[N=3$; summary relative risk (SRR), 0.92; 95\% CI, 0.85-0.98]. Albeit, this decreased risk was not observed when analyzing studies that adjusted for BMI $(N=$ 6). For liver and pancreatic cancer, no statistically significant decreased risks were found (SRR 0.77, 95\% CI, 0.38-1.55 and $0.65,95 \%$ CI, 0.39-1.08, respectively).

Certain limitations of our study merit discussion. First, it is possible that the results are not without any residual confounding due to our inability to correct for lifestyle factors (e.g., obesity, alcohol use, smoking status, and physical activity), diabetes severity (HbA1c), dietary habits, and the presence of unmeasured comorbidities (e.g., gastro-esophageal reflux disease, chronic liver disease, or chronic pancreatitis). Second, a lack of statistical power existed for some cancer sites, such as liver cancer, and biliary tract cancer, especially in the sensitivity analyses wherein a new-user cohort was used. This resulted in a limited ability to statistically adjust for confounders in the multivariate analyses. Third, confounding by indication could have influenced the results, which we tried to minimize by including a cohort of ADD users only. Metformin is prescribed more readily to obese diabetic patients, as it may contribute to weight loss. In turn, obesity and its proxy indicator, high BMI, are closely linked to GI cancer risk (42). Furthermore, although we compared metformin use with the use of other NIADs, the majority of other NIAD users was comprised of SU users with or without other NIADs (excluding metformin). Fourth, most GI cancers take decades to form, and the average follow-up time per person was 4.9 years. It is possible that the null results found in our study may be explained by the fact that most cancers were already present when patients started using metformin. Yet, we also do not know if metformin use may be able to slow down tumor progression, thereby delaying its diagnosis. Lastly, statistically significant inverse associations were found for GI cancer risk in past other NIAD users. The reasons, however, for becoming a past other NIAD user may vary greatly (e.g., start of insulin monotherapy or missing data due to a patient switching to a pharmacy outside the PHARMO catchment area). Therefore, the group of "past other NIAD use" is a very heterogeneous group, and no valid conclusions can be drawn from the point estimates in this group.

One of the major strengths of this study was the availability of complete and longitudinal drug dispensing data from PHARMO Database Network, which allowed us to model drug exposure during follow-up in a time-varying way. Furthermore, these drug dispensing data are derived directly from community pharmacies in the overlapping NCR-PHARMO region, with each dispensing being either picked up by the patient or directly delivered to the patient's address. Therefore, these data come very close to actual drug intake by the patient. In addition, cancer data from the NCR are known to contain high-quality data over a wide range of cancers and cancer characteristics, which guarantees a high level of cancer ascertainment. Furthermore, to account for prevalent user bias, we repeated the analyses in incident NIAD users. Inclusion of prevalent users in the main analyses could potentially introduce two biases. First, prevalent users probably have a survival benefit over incident users, as they are survivors of the early phase of therapy and make up a "survivor cohort" that generally consists of healthier patients. Secondly, prevalent drug use might alter the levels of risk factors (e.g., obesity, insulin resistance) over time, causing these risk factors to lose their confounding effect (17).

In summary, we found that in current metformin users, the risks of GI cancer were not significantly different from current other NIAD users. Our data add to the evidence of recent publications and highlight that methodological standards for drug exposure definitions should be met in observational studies. Future meta- 
de Jong et al.

analyses will benefit from an in-depth description of possible (time-related) biases and confounding factors in all included studies, and by performing stratified analyses by studies with a low level of confounding and bias.

\section{Disclosure of Potential Conflicts of Interest}

No potential conflicts of interest were disclosed.

\section{Authors' Contributions}

Conception and design: R.G. de Jong, A.A. Masclee, F. de Vries, M.L. JanssenHeijnen

Development of methodology: R.G. de Jong, A.M. Burden, F. de Vries, M.L. Janssen-Heijnen

Acquisition of data (provided animals, acquired and managed patients, provided facilities, etc.): R.G. de Jong, M.P. van Herk-Sukel, P.A. Vissers, F. de Vries

Analysis and interpretation of data (e.g., statistical analysis, biostatistics, computational analysis): R.G. de Jong, A.M. Burden, S. de Kort, P.A. Vissers, F. de Vries, M.L. Janssen-Heijnen

\section{References}

1. Bouma M, Rutten GE, de Grauw WJ, Wiersma T, Goudswaard AN, Nederlands Huisartsen G. Summary of the practice guideline 'Diabetes mellitus type 2' (second revision) from the Dutch College of General Practitioners. Ned Tijdschr Geneeskd 2006;150:2251-6.

2. Wulffele MG, Kooy A, de Zeeuw D, Stehouwer CD, Gansevoort RT. The effect of metformin on blood pressure, plasma cholesterol and triglycerides in type 2 diabetes mellitus: A systematic review. J Intern Med 2004;256: $1-14$.

3. Giovannucci E, Harlan DM, Archer MC, Bergenstal RM, Gapstur SM, Habel LA, et al. Diabetes and cancer: A consensus report. CA Cancer J Clin 2010;60:207-21.

4. Pollak MN. Investigating metformin for cancer prevention and treatment: The end of the beginning. Cancer Discov 2012;2:778-90.

5. Dowling RJ, Goodwin PJ, Stambolic V. Understanding the benefit of metformin use in cancer treatment. BMC Med 2011;9:33.

6. Shaw RJ, Lamia KA, Vasquez D, Koo SH, Bardeesy N, Depinho RA, et al. The kinase LKB1 mediates glucose homeostasis in liver and therapeutic effects of metformin. Science 2005;310:1642-6.

7. Hirsch HA, Iliopoulos D, Struhl K. Metformin inhibits the inflammatory response associated with cellular transformation and cancer stem cell growth. Proc Natl Acad Sci U S A 2013;110:972-7.

8. Libby G, Donnelly LA, Donnan PT, Alessi DR, Morris AD, Evans JM. New users of metformin are at low risk of incident cancer: A cohort study among people with type 2 diabetes. Diabetes Care 2009;32:1620-5.

9. Currie CJ, Poole CD, Gale EA. The influence of glucose-lowering therapies on cancer risk in type 2 diabetes. Diabetologia 2009;52:1766-77.

10. Bodmer M, Becker C, Meier C, Jick SS, Meier CR. Use of antidiabetic agents and the risk of pancreatic cancer: A case-control analysis. Am J Gastroenterol 2012;107:620-6.

11. Bodmer M, Becker C, Meier C, Jick SS, Meier CR. Use of metformin is not associated with a decreased risk of colorectal cancer: A case-control analysis. Cancer Epidemiol Biomarkers Prev 2012;21:280-6.

12. Chiu CC, Huang CC, Chen YC, Chen TJ, Liang Y, Lin SJ, et al. Increased risk of gastrointestinal malignancy in patients with diabetes mellitus and correlations with anti-diabetes drugs: A nationwide population-based study in Taiwan. Intern Med 2013;52:939-46.

13. Lee MS, Hsu CC, Wahlqvist ML, Tsai HN, Chang YH, Huang YC. Type 2 diabetes increases and metformin reduces total, colorectal, liver and pancreatic cancer incidences in Taiwanese: A representative population prospective cohort study of 800,000 individuals. BMC Cancer 2011; $11: 20$.

14. Donadon V, Balbi M, Mas MD, Casarin P, Zanette G. Metformin and reduced risk of hepatocellular carcinoma in diabetic patients with chronic liver disease. Liver Int 2010;30:750-8.

15. Sehdev A, Shih YC, Vekhter B, Bissonnette MB, Olopade OI, Polite BN. Metformin for primary colorectal cancer prevention in patients with
Writing, review, and/or revision of the manuscript: R.G. de Jong, A.M. Burden, S. de Kort, M.P. van Herk-Sukel, P.A. Vissers, P.K. Janssen, H.R. Haak, A.A. Masclee, F. de Vries, M.L. Janssen-Heijnen

Administrative, technical, or material support (i.e., reporting or organizing data, constructing databases): R.G. de Jong

Study supervision: A.M. Burden, A.A. Masclee, F. de Vries, M.L. JanssenHeijnen

\section{Acknowledgments}

We thank J.H.M. Driessen for her support during the process of data analysis.

The costs of publication of this article were defrayed in part by the payment of page charges. This article must therefore be hereby marked advertisement in accordance with 18 U.S.C. Section 1734 solely to indicate this fact.

Received October 31, 2016; revised December 21, 2016; accepted March 1, 2017; published OnlineFirst March 8, 2017.

diabetes: A case-control study in a US population. Cancer 2015;121: 1071-8.

16. Suissa S, Azoulay L. Metformin and the risk of cancer: Time-related biases in observational studies. Diabetes care 2012;35:2665-73.

17. Golozar A, Liu S, Lin JA, Peairs K, Yeh HC. Does metformin reduce cancer risks? Methodologic considerations. Curr Diab Rep 2016;16:4.

18. Yang XL, Ma RC, So WY, Kong AP, Xu G, Chan JC. Addressing different biases in analysing drug use on cancer risk in diabetes in non-clinical trial settings-what, why and how? Diabetes Obes Metab 2012;14:579-85.

19. Knapen LM, Dittrich ST, de Vries F, Starup-Linde J, Vestergaard P, Henry $\mathrm{RM}$, et al. Use of biguanides and the risk of colorectal cancer: A registerbased cohort study. Curr Drug Saf 2013;8:349-56.

20. Smiechowski B, Azoulay L, Yin H, Pollak MN, Suissa S. The use of metformin and colorectal cancer incidence in patients with type II diabetes mellitus. Cancer Epidemiol Biomarkers Prev 2013;22:1877-83.

21. van Herk-Sukel MP, van de Poll-Franse LV, Lemmens VE, Vreugdenhil G, Pruijt JF, Coebergh JW, et al. New opportunities for drug outcomes research in cancer patients: The linkage of the Eindhoven Cancer Registry and the PHARMO Record Linkage System. Eur J Cancer 2010;46:395-404.

22. WHO Collaborating Centre for Drug Statistics methodology. ATC Index with DDD's. Oslo: WHO. 2016.

23. International Classification of Diseases of Oncology. Version 2013; first edition. Geneva: World Health Organization; 1976.

24. Gong Z, Aragaki AK, Chlebowski RT, Manson JE, Rohan TE, Chen C, et al. Diabetes, metformin and incidence of and death from invasive cancer in postmenopausal women: Results from the women's health initiative. Int J Cancer 2016;138:1915-27.

25. Wang SY, Chuang CS, Muo CH, Tu ST, Lin MC, Sung FC, et al. Metformin and the incidence of cancer in patients with diabetes: A nested case-control study. Diabetes Care 2013;36:e155-6.

26. But A, Wang H, Mannisto S, Pukkala E, Haukka J. Assessing the effect of treatment duration on the association between anti-diabetic medication and cancer risk. PLoS One 2014;9:e113162.

27. Tsilidis KK, Capothanassi D, Allen NE, Rizos EC, Lopez DS, van Veldhoven $\mathrm{K}$, et al. Metformin does not affect cancer risk: a cohort study in the U.K Clinical Practice Research Datalink analyzed like an intention-to-treat trial. Diabetes Care 2014;37:2522-32.

28. Walker EJ, Ko AH, Holly EA, Bracci PM. Metformin use among type 2 diabetics and risk of pancreatic cancer in a clinic-based case-control study. Int J Cancer 2015;136:E646-53.

29. Agrawal S, Patel P, Agrawal A, Makhijani N, Markert R, Deidrich W. Metformin use and the risk of esophageal cancer in Barrett esophagus. South Med J 2014;107:774-9.

30. Miele L, Bosetti C, Turati F, Rapaccini G, Gasbarrini A, La Vecchia C, et al. Diabetes and insulin therapy, but not metformin, are related to hepatocellular cancer risk. Gastroenterol Res Pract 2015;2015:570356. 
31. Kowall B, Stang A, Rathmann W, Kostev K. No reduced risk of overall, colorectal, lung, breast, and prostate cancer with metformin therapy in diabetic patients: Database analyses from Germany and the UK. Pharmacoepidemiol Drug Saf 2015;24:865-74.

32. Karlstad O, Starup-Linde J, Vestergaard P, Hjellvik V, Bazelier MT, Schmidt $\mathrm{MK}$, et al. Use of insulin and insulin analogs and risk of cancer - systematic review and meta-analysis of observational studies. Curr Drug Saf 2013; $8: 333-48$.

33. Soranna D, Scotti L, Zambon A, Bosetti C, Grassi G, Catapano A, et al Cancer risk associated with use of metformin and sulfonylurea in type 2 diabetes: A meta-analysis. Oncologist 2012;17:813-22.

34. Zhang P, Li H, Tan X, Chen L, Wang S. Association of metformin use with cancer incidence and mortality: A meta-analysis. Cancer Epidemiol 2013; 37:207-18.

35. Wang Z, Lai ST, Xie L, Zhao JD, Ma NY, Zhu J, et al. Metformin is associated with reduced risk of pancreatic cancer in patients with type 2 diabetes mellitus: A systematic review and meta-analysis. Diabetes Res Clin Pract 2014;106:19-26.

36. Decensi A, Puntoni M, Goodwin P, Cazzaniga M, Gennari A, Bonanni B, et al. Metformin and cancer risk in diabetic patients: A systematic review and meta-analysis. Cancer Prev Res (Phila) 2010;3:1451-61.
37. Noto H, Goto A, Tsujimoto T, Noda M. Cancer risk in diabetic patients treated with metformin: A systematic review and meta-analysis. PLoS One 2012; 7:e33411.

38. Singh S, Singh H, Singh PP, Murad MH, Limburg PJ. Antidiabetic medications and the risk of colorectal cancer in patients with diabetes mellitus: A systematic review and meta-analysis. Cancer Epidemiol Biomarkers Prev 2013;22:2258-68.

39. Singh S, Singh PP, Singh AG, Murad MH, McWilliams RR, Chari ST. Antidiabetic medications and risk of pancreatic cancer in patients with diabetes mellitus: A systematic review and meta-analysis. Am J Gastroenterol 2013;108:510-9; quiz 20.

40. Singh S, Singh PP, Singh AG, Murad MH, Sanchez W. Anti-diabetic medications and the risk of hepatocellular cancer: A systematic review and meta-analysis. Am J Gastroenterol 2013;108:881-91; quiz 92.

41. Gandini S, Puntoni M, Heckman-Stoddard BM, Dunn BK, Ford L, DeCensi A, et al. Metformin and cancer risk and mortality: A systematic review and meta-analysis taking into account biases and confounders. Cancer Prev Res (Phila) 2014;7:867-85.

42. Donohoe CL, O'Farrell NJ, Doyle SL, Reynolds JV. The role of obesity in gastrointestinal cancer: Evidence and opinion. Therap Adv Gastroenterol 2014;7:38-50. 


\section{Cancer Prevention Research}

\section{No Decreased Risk of Gastrointestinal Cancers in Users of Metformin in The Netherlands; A Time-Varying Analysis of Metformin Exposure}

Roy G. de Jong, Andrea M. Burden, Sander de Kort, et al.

Cancer Prev Res 2017;10:290-297. Published OnlineFirst March 8, 2017.

\begin{tabular}{|rl|} 
Updated version & $\begin{array}{l}\text { Access the most recent version of this article at: } \\
\text { doi:10.1158/1940-6207.CAPR-16-0277 }\end{array}$ \\
$\begin{array}{r}\text { Supplementary } \\
\text { Material }\end{array}$ & $\begin{array}{l}\text { Access the most recent supplemental material at: } \\
\text { http://cancerpreventionresearch.aacrjournals.org/content/suppl/2017/03/08/1940-6207.CAPR-16-0277.DC } \\
1\end{array}$ \\
\hline
\end{tabular}

Cited articles This article cites 40 articles, 13 of which you can access for free at:

http://cancerpreventionresearch.aacrjournals.org/content/10/5/290.full\#ref-list-1

E-mail alerts Sign up to receive free email-alerts related to this article or journal.

Reprints and To order reprints of this article or to subscribe to the journal, contact the AACR Publications Department at Subscriptions pubs@aacr.org.

Permissions To request permission to re-use all or part of this article, use this link

http://cancerpreventionresearch.aacrjournals.org/content/10/5/290.

Click on "Request Permissions" which will take you to the Copyright Clearance Center's (CCC)

Rightslink site. 